\title{
The Impact of 950MHz Electromagnetic Radiation on the Brain and Liver of Rats and the Role of Garlic Treatment
}

\author{
S.M. Shedid", Gh.A. El-Tawill, F.R. Algeda, N.M. El-Fatih, N.A. Eltahawy \\ Radiation Biology Department, National Center for Radiation Research and \\ Technology (NCRRT), Atomic Energy Authority (AEA), Cairo, Egypt.
}

\begin{abstract}
$\mathbf{T}$ THE USE of mobile phones, laptops and wireless networks has become essential components of daily life. However, despite they make life easier, they may also cause a number of health problems.

This study aims at investigating the changes induced in the liver and brain of male albino rats caused by the exposure to $950 \mathrm{MHz}$ and the role of garlic treatment. Male Albino rats were exposed to $950 \mathrm{MHz}$ electromagnetic field (power density of $1 \mathrm{~mW} / \mathrm{cm}^{2}$ ). Whole body average specific absorption rates (SAR) were 0.238 and 0.372 , respectively, for duration of one hour, thrice a week for a period of seven weeks. Garlic extract was administered to the rats at a dose of $500 \mathrm{mg} / \mathrm{kg}$ body weight, half an hour before each exposure. Animals were sacrificed one day post the last exposure dose. Exposure to $950 \mathrm{MHz}$ has triggered oxidative stress in both tissues verified by a significant increase of malondialdehyde (MDA) and nitric oxide (NO) associated with a significant decrease in the activity of superoxide dismutase (SOD), catalase (CAT) and glutathione peroxidase (GSH-Px). Exposure to $950 \mathrm{MHz}$ has also induced alteration in the xanthine oxidoreductase system (XOR) identified by a significant increase in the activity of xanthine oxidase $(\mathrm{XO})$ concomitant to a significant decrease of xanthine dehydrogenase. The results showed also accumulation of iron $(\mathrm{Fe})$, and cupper $(\mathrm{Cu})$, and decreases in zinc $(\mathrm{Zn})$ and manganese (Mn). Garlic extract treatment has significantly improved these changes. In conclusion, Garlic might attenuate the impact of $950 \mathrm{MHz}$ in liver and brain of male rats.
\end{abstract}

Keywords: Garlic, Electromagnetic radiation (EMR), Brain, liver, Oxidative stress, Trace elements.

\section{Introduction}

Electromagnetic radiation ranges from very high-energy radiation (high frequency, short wave length) to very low-energy radiations (low frequency, long wave length). High-energy radiations include $\mathrm{X}$-rays and gamma rays and are termed as ionizing radiation, which means that they have enough energy to remove an electron from an atom or a molecule. Ionizing radiation can cause a significant biological damage (Shedid et al., 2018). Low-energy radiations as the radiofrequency waves and microwaves are called non-ionizing radiation. Non-ionizing radiation has sufficient energy only for excitation, the movement of an electron to a higher energy state, but does not carry enough energy to ionize atoms or molecules. This does not exclude non-ionizing radiation from being injurious to humans (Megha et al., 2012 and Demers et al., 2014). Headache, decreased learning potential, poor concentration, and oxidative stress were reported (Calcabrini et al., 2017 and Ahmed et al., 2017).

The biological impacts of the radiofrequency and microwaves have been classified as thermal and non-thermal. The thermal effect is caused by the absorption of energy by the skin and superficial tissues and its conversion to heat (Challis, 2005). The non-thermal effect is associated with the amount of energy absorbed and mediated by the generation of reactive oxygen species (ROS) (Tkalec et al., 2007).

Studies concerned with the deleterious effects of the radiofrequency waves and microwaves demonstrated that they can induce damage to the

\footnotetext{
${ }^{\#}$ Corresponding author email: shereen_biochemistry@hotmail.com $\quad$ Tel: +201002616313 
brain, liver, kidney and reproductive system (Hao et al., 2015; Deniz et al., 2017 and Sepehrimanesh et al., 2017). However, although numerous studies demonstrated that they can affect vital organs (Yu \& Peng, 2017, Samta et al., 2017 and Kivrak et al., 2017), their biological effects are still controversial due to many exposure parameters such as frequency, orientation, modulation, power density, and duration of exposure.

Mammalian XOR exists in two interconvertible forms, xanthine oxidase (XO) and xanthine dehydrogenase $(\mathrm{XDH})$ which predominates in vivo. Both forms of the enzyme reduce molecular oxygen, although only XDH can reduce $\mathrm{NAD}^{+}$, which is its preferred electron acceptor. Reduction of oxygen generates the ROS, superoxide anion, and hydrogen peroxide, and because of this, XOR has been implicated as a destructive agent, particularly in many forms of ischemia-reperfusion (IR) injury (Harrison, 2002 and Meneshian \& Bulkley, 2002).

Regulation of reducing and oxidizing (redox) state is critical for cell viability, activation, proliferation, and organ function. Aerobic organisms have integrated antioxidant systems, which include enzymatic and nonenzymatic antioxidants that are usually effective in blocking harmful effects of ROS. The major enzymatic antioxidants are SODs, catalase, and GSH-Px. Since superoxide is the primary ROS produced from a variety of sources, its dismutation by SOD is of primary importance for each cell (Zelko et al., 2002). The $\mathrm{H}_{2} \mathrm{O}_{2}$ produced is reduced to water by catalase (Kirkman et al., 1999) and the GSH-Px (Flohé, 1988).

In order to overcome the potential harmful effect of free radicals and to reduce the damage by oxidants, many natural substances have been tried as antioxidants. Garlic has been used for culinary and medicinal purposes by people from many cultures for centuries (Lawson, 1998). Garlic is a particularly rich source of organosulfur compounds, which are thought to be responsible for its flavor and aroma, as well as its potential health benefits. Consumer interest in the health benefits of garlic is strong enough to place it among the bestselling herbal supplements in the United States (Blumenthal, 2005). Scientists are interested in the potential for organosulfur compounds derived from garlic to prevent and treat chronic diseases, such as cancer and cardiovascular disease (Tapiero et al.,
2004). Alliums sativum or garlic, contains various substances including minerals, carbohydrates, proteins, fats and vitamins. Vitamins found in garlic include vitamin A, various kinds of vitamin $\mathrm{B}$, such as riboflavin, thiamine, nicotinic acid, and vitamins $\mathrm{C}$ and $\mathrm{E}$. Garlic is one of these plant products, traditionally used for its cytotoxic, antitumor, antifungal, antibacterial, antiviral and anti protozoal properties. In an elegant study, Duvvu et al. (2018) revealed that Buffalo Calves supplemented with garlic powder at the dose rate of 250 as well as $300 \mathrm{mg}$ per $\mathrm{kg}$ body weight, for a period of 90 days showed a significant increase in the total protein, albumin, globulin and HDLcholesterol levels and a significant decrease in the blood glucose level, and serum cholesterol level compared with the control group calves.

This work is conducted to determine the effect of $950 \mathrm{MHz}$ on the liver, and brain of male albino rats by measuring the oxidant/antioxidant status, and changes in the level of trace elements, and to evaluate the role of garlic treatment in the alleviation of these changes.

\section{Materials and Methods}

\section{Experimental animals}

Male Albino rats were obtained from the Atomic Energy Authority, National Center for Radiation Research and Technology (NCRRT). Rats 3-4 month's age, weighing $(200 \pm 10 \mathrm{~g})$, were used as experimental animals. The animals were maintained under standard conditions of temperature, humidity and lighting with free access to standard food and drinking water ad libitum, and kept under observation for one week prior to experimentation. All animal procedures were performed in accordance with the Ethics Committee of the National Research Center, conformed to the Guide for the care and use of Laboratory Animals, published by the National Institutes of Health (NIH publication No.85-23, revised 1996).

\section{Irradiation process}

Exposure of rats to $950 \mathrm{MHz}$ was carried out at the NCRRT Atomic Energy Authority, Cairo, Egypt. The animals were exposed to an electromagnetic field (EMF) exposure system, generated from a synthesized $\mathrm{CW}$ generator, model $83712 \mathrm{~b}$, with around tube cage and adipole exposure antenna was used to produce EMF with frequency of $950 \mathrm{MHz}$ at power densities $1 \mathrm{~mW} /$ $\mathrm{cm}^{2}$ (Durney et al., 1986). Rats were exposed to 
the EMF 3 times a week, each time lasts for one hour, for 7 weeks.

\section{Preparation of garlic extract}

Fresh garlic was purchased from a local grocery store. The garlic extract was prepared according to the method reported by Alnaqeeb et al. (1999). In brief, the fresh garlic cloves were peeled on crushed ice, and $50 \mathrm{~g}$ of garlic was homogenized in $75 \mathrm{ml}$ of cold, distilled water in the presence of some crushed ice. The filtered homogenized mixture was then centrifuged at $2000 \times \mathrm{g}$ for $10 \mathrm{~min}$ and the clear supernatant was made up to $100 \mathrm{ml}$ with distilled water. The concentration of the garlic preparation was considered to be $500 \mathrm{mg} / \mathrm{ml}$. The prepared garlic extract was stored at $-20^{\circ} \mathrm{C}$ until being used. The extract was given to the rats at a dose of $500 \mathrm{mg} /$ $\mathrm{kg}$ body weight, half an hour before each EMF exposure

\section{Animal groups}

Experimental animals were randomly divided into 4 groups of 6 rats each, as follows, group I (Control group): Rats received distilled water via gavages for seven weeks; group II (Garlic group): Rats orally received $500 \mathrm{mg} / \mathrm{kg}$ b.w. of garlic extract three times a week (day after day) for seven weeks. Group III (Irradiated group): Rats were exposed to $950 \mathrm{MHz}$ EMF for $1 \mathrm{hr}$ three times a week (day after day) for seven weeks, group IV (Garlic - Irradiated group): Rats orally administered with $500 \mathrm{mg} / \mathrm{kg}$ b.w. of garlic extract and exposed to $950 \mathrm{MHz}$ EMF for $1 \mathrm{hr}$ three times a week (day after day) for 7 weeks after half hour of the garlic dosage.

\section{Biochemical analysis}

All chemicals and kits were obtained from Sigma-Aldrich, St Louis, MO, USA. Measurement of absorbance was done using a T60 UV/VIS spectrophotometer (PG instruments, London, UK). At the end of the experimental period (7weeks), rats from each group were sacrificed by decapitation one day post the last EMF exposure. For the assessment of oxidative stress, the liver and brain tissues were rapidly excised and $10 \%$ $(\mathrm{w} / \mathrm{v})$ tissue homogenate was prepared in normal $0.9 \%$ saline using Teflon homogenizer (GlassCol, Terre Haute, Ind., USA). The homogenates were centrifuged at $10,000 \mathrm{~g}$ for $15 \mathrm{~min}$ using refrigerated centrifuge (K3 Centurion Scientific, Ltd, London, UK) and aliquots of the supernatant were separated and used for further analysis.
Lipid peroxidation was assayed according to Yoshioka et al. (1979). The method is based on the determination of malondialdehyde (MDA) an end product of lipid peroxidation, which reacts with thiobarbituric acid in acidic medium to yield a pink colored trimethine complex exhibiting an absorption maximum at 532nm. Nitric oxide (NO) level was determined following the procedure described by Miranda et al. (2001), based on the measurement of total nitrite levels which is the only stable end product of the autoxidation of $\mathrm{NO}$ in aqueous solution (formed by reaction of NO with superoxide or oxyhemoglobin) which provides a reliable and quantitative estimate of NO output in vivo. Vanadium (III) in dilute acid solution effects the quantitative reduction of nitrate to nitrite and/or nitric oxide, both of which are captured by Griess reagents. The Griess reaction entails formation of a chromophore from the diazotization of sulfanilamide by acidic nitrite followed by coupling with bicyclic amines such as $\mathrm{N}$-1- (napthyl)-ethylenediamine, which results in a measurable pink metabolite measured at $540 \mathrm{~nm}$.

Superoxide dismutase activity (SOD) was determined according to the method of Niskikimi et al. (1972). The assay relies on the ability of the enzyme to inhibit the phenazinemethosulfatemediated reduction of nitrobluetetrazolium (NBT) dye. The increase in absorbance at $560 \mathrm{~nm}$ due to the formation of reduced NBT was recorded in a spectrophotometer. Catalase activity was determined according to Aebi (1984) in which the disappearance of peroxide is followed spectrophotometrically at $240 \mathrm{~nm}$. The method is based on the catalytic function of the enzyme where it catalyzes the decomposition of $\mathrm{H}_{2} \mathrm{O}_{2}$ into water and oxygen. Glutathione peroxidase (GSHPx) activity was determined according to the method of Paglia \& Valentine (1967). GSH-Px reduces $\mathrm{H}_{2} \mathrm{O}_{2}$ to water by oxidizing the reduced glutathione (GSH) to glutathione disulfide (GSSG) giving a deep yellow color measured spectrophotometrically at $340 \mathrm{~nm}$.

The xanthine oxidoreductase (XOR) system, which consists of xanthine dehydrogenase (XDH) and xanthine oxidase (XO) were assayed using the method of Kaminski \& Jezewska (1979). The xanthine oxidoreductase activity was measured spectrophotometrically as formation of uric acid and NADH at 302 and 340nm, respectively. The reaction mixture contained $50 \mathrm{mM}$ xanthine, 
$150 \mathrm{mM}$ tris-HCL and the protein samples. The total activity $(\mathrm{XDH}+\mathrm{XO})$ was determined at the same wavelength by adding NAD $(150 \mathrm{mM})$ to the reaction mixture. The reaction mixture (without tissue extract) was mixed and incubated at $25^{\circ} \mathrm{C}$ for $5 \mathrm{~min}$. The reaction was started by adding the enzyme (tissue extract) and the progress of the reaction was monitored after an initial delay of $2 \mathrm{~min}$. The activity of XDH was calculated by subtracting the $\mathrm{XO}$ activity from the total activity $(\mathrm{XDH}+\mathrm{XO})$. One unit of enzyme activity was defined as amount of enzyme required to catalyze the formation of $1 \mu \mathrm{mol}$ of uric acid per minute at $25^{\circ} \mathrm{C}$. The enzyme activity was expressed as $\mathrm{mU} /$ mg protein.

The levels of total iron, total copper, total zinc, and total manganese were measured by thermo scientific ice 3000 series atomic absorption spectrophotometer according to the method of Kirbright \& Sargent (1974).

\section{Statistical analysis}

The data is presented as mean \pm standard deviation (SD). Groups were compared by oneway analyses of variance (ANOVA), and post hoc multiple comparisons were done with LSD test using SPSS/PC software program (version 21; SPSS Inc., Chicago, IL, USA).

\section{$\underline{\text { Results }}$}

The administration of Garlic extract, to normal rats, has not affected the level of malondialdehyde (MDA) and Nitric oxide (NO) as well as xanthine oxidase (XO) and xanthine dehydrogenase $(\mathrm{XDH})$ activities, in the brain and liver tissue of rats (Tables 1 and 2). The activity of antioxidant enzymes superoxide dismutase (SOD), catalase (CAT) and glutathione peroxidase (GSH-Px) was in the normal level (Table 3). There was no significant change recorded for the levels of total iron, copper, zinc, and manganese, in the liver and brain of rats (Table 4).

TABLE 1. The level of malondialdehyde (MDA) and nitric oxide (NO) in the liver and brain of rats in the different groups.

\begin{tabular}{lccccc}
\hline & Organ & Control & Garlic & EMF & Garlic+EMF \\
\hline & Liver & $237 \pm 4.1$ & $\begin{array}{c}234 \pm 6.1 \\
(-1 \%)>0.05^{\mathrm{a}}\end{array}$ & $\begin{array}{c}289 \pm 6.6 \\
(+22 \%) \leq 0.001^{\mathrm{a}}\end{array}$ & $\begin{array}{c}250 \pm 3.7 \\
(+5 \%) \leq 0.01^{\mathrm{a}} \leq 0.001^{\mathrm{b}}\end{array}$ \\
$\begin{array}{l}\text { MDA } \\
(\mathrm{nmol} / \mathrm{g} \text { tissue })\end{array}$ & Brain & $152 \pm 5.6$ & $\begin{array}{c}150 \pm 3.4 \\
(-1 \%)>0.05^{\mathrm{a}}\end{array}$ & $\begin{array}{c}179 \pm 3.3 \\
(+18 \%) \leq 0.001^{\mathrm{a}}\end{array}$ & $\begin{array}{c}159 \pm 3.4 \\
(+5 \%) \leq 0.01^{\mathrm{a}} \leq 0.001^{\mathrm{b}}\end{array}$ \\
& Liver & $24 \pm 3$ & $22 \pm 2$ & $34 \pm 1.6$ & $27 \pm 2.1$ \\
NO & & $(-8)>0.05^{\mathrm{a}}$ & $(+42 \%) \leq 0.001^{\mathrm{a}}$ & $(+13 \%) \leq 0.01^{\mathrm{a}} \leq 0.001^{\mathrm{b}}$ \\
$(\mathrm{nmole} / \mathrm{g}$ tissue $)$ & Brain & $20 \pm 1.6$ & $\begin{array}{c}18 \pm 1.5 \\
(-10 \%)>0.05^{\mathrm{a}}\end{array}$ & $\begin{array}{c}25 \pm 1.7 \\
(+25 \%) \leq 0.001^{\mathrm{a}}\end{array}$ & $\begin{array}{c}22 \pm 1.9 \\
(+10 \%)>0.05^{\mathrm{a}} \leq 0.001^{\mathrm{b}}\end{array}$ \\
\hline
\end{tabular}

- Data are expressed as means \pm standard deviation $(n=6)$.

- The number between brackets shows the percentage of change from the respective control value.

- a: Significance vs control, b: Significance vs EM.

- Differences between means were considered significant at $\mathrm{P} \leq 0.05$, highly significant at $p \leq 0.01$ and very highly significant at $\mathrm{P} \leq 0.001$, non-significant at $\mathrm{P}>0.05$.

TABLE 2. The values of the xanthine oxidoreductase system in the liver and brain of rats in the different groups.

\begin{tabular}{|c|c|c|c|c|c|}
\hline & Organ & Control & Garlic & EMF & Garlic+EMF \\
\hline \multirow{2}{*}{$\begin{array}{l}\text { Xanthine Oxidase } \\
\text { (mU/mg protein) }\end{array}$} & Liver & $2.13 \pm 0.02$ & $\begin{array}{c}2.04 \pm 0.05 \\
(-4 \%)>0.05^{a}\end{array}$ & $\begin{array}{c}2.90 \pm 0.38 \\
(+38 \%) \leq 0.001^{\mathrm{a}}\end{array}$ & $\begin{array}{c}2.17 \pm 0.19 \\
(+2 \%)>0.05^{\mathrm{a}} \leq 0.001^{\mathrm{b}}\end{array}$ \\
\hline & Brain & $1.28 \pm 0.03$ & $\begin{array}{c}1.25 \pm 0.05 \\
(-2 \%)>0.05^{a}\end{array}$ & $\begin{array}{c}1.70 \pm 0.14 \\
(+31 \%) \leq 0.001^{\mathrm{a}}\end{array}$ & $\begin{array}{c}1.42 \pm 0.08 \\
(+9 \%) \leq 0.01^{\mathrm{a}} \leq 0.001^{\mathrm{b}}\end{array}$ \\
\hline \multirow{2}{*}{$\begin{array}{l}\text { Xanthine Dehydrogenase } \\
\text { (mU/mg protein) }\end{array}$} & Liver & $4.9 \pm 0.20$ & $\begin{array}{c}5.0 \pm 0.02 \\
(2 \%)>0.05^{\mathrm{a}}\end{array}$ & $\begin{array}{c}3.1 \pm 0.11 \\
(-37 \%) \leq 0.001^{a}\end{array}$ & $\begin{array}{c}4.5 \pm 0.15 \\
(-8 \%) \leq 0.01^{\mathrm{a}} \leq 0.001^{\mathrm{b}}\end{array}$ \\
\hline & Brain & $2.61 \pm 0.39$ & $\begin{array}{c}2.63 \pm 0.42 \\
(0.8 \%)>0.05^{\mathrm{a}}\end{array}$ & $\begin{array}{c}1.67 \pm 0.11 \\
(-35 \%) \leq 0.001^{\mathrm{a}}\end{array}$ & $\begin{array}{c}2.42 . \pm 0.31 \\
(-8 \%)>0.05^{\mathrm{a}} \leq 0.001^{\mathrm{b}}\end{array}$ \\
\hline
\end{tabular}

- Data are expressed as means \pm standard deviation $(n=6)$.

- The number between brackets shows the percentage of change from the respective control value.

- a: Significance vs control, b: Significance vs EM.

- Differences between means were considered significant at $\mathrm{P} \leq 0.05$, highly significant at $p \leq 0.01$ and very highly significant at $\mathrm{P} \leq 0.001$, non-significant at $\mathrm{P}>0.05$. 
TABLE 3. The activity of superoxide dismutase (SOD), catalase (CAT) and glutathione peroxidase (GSH-Px) in the liver and brain of rats in the different groups.

\begin{tabular}{|c|c|c|c|c|c|}
\hline & Organ & Control & Garlic & EMF & Garlic+EMF \\
\hline \multirow{2}{*}{$\begin{array}{l}\text { SOD } \\
\text { (U/g fresh tissue) }\end{array}$} & Liver & $132 \pm 6.2$ & $\begin{array}{c}135 \pm 5.3 \\
(+2 \%)>0.05^{\mathrm{a}}\end{array}$ & $\begin{array}{c}95 \pm 3.9 \\
(-28 \%) \leq 0.001^{a}\end{array}$ & $\begin{array}{c}120 \pm 2.9 \\
(-9 \%) \leq 0.01^{\mathrm{a}} \leq 0.001^{\mathrm{b}}\end{array}$ \\
\hline & Brain & $155 \pm 7.4$ & $\begin{array}{c}153 \pm 7.5 \\
(-1.2 \%)>0.05^{a}\end{array}$ & $\begin{array}{c}110 \pm 5.9 \\
(-29 \%) \leq 0.001^{\mathrm{a}}\end{array}$ & $\begin{array}{c}132 \pm 4.4 \\
(-15 \%) \leq 0.01^{\mathrm{a}} \leq 0.001^{\mathrm{b}}\end{array}$ \\
\hline \multirow{2}{*}{$\begin{array}{l}\text { CAT } \\
\text { (U/g fresh tissue) }\end{array}$} & Liver & $12.4 \pm 0.2$ & $\begin{array}{c}12.3 \pm 0.5 \\
(-0.8 \%)>0.05^{a}\end{array}$ & $\begin{array}{c}8.4 \pm 0.3 \\
(-32 \%) \leq 0.001^{a}\end{array}$ & $\begin{array}{c}10.9 \pm 0.5 \\
(-12 \%) \leq 0.01^{\mathrm{a}} \leq 0.001^{\mathrm{b}}\end{array}$ \\
\hline & Brain & $5.7 \pm 0.2$ & $\begin{array}{c}5.4 \pm 0.5 \\
(-5.2 \%)>0.05^{\mathrm{a}}\end{array}$ & $\begin{array}{c}4 \pm 0.14 \\
(-30 \%) \leq 0.001^{a}\end{array}$ & $\begin{array}{c}4.9 \pm 0.13 \\
(-14 \%) \leq 0.01^{\mathrm{a}} \leq 0.001^{\mathrm{b}}\end{array}$ \\
\hline \multirow{2}{*}{$\begin{array}{l}\text { GSH-Px } \\
\text { (mg consumed } \\
\text { glutathione/min/g } \\
\text { fresh tissue) }\end{array}$} & Liver & $1.2 \pm 0.19$ & $\begin{array}{c}1.3 \pm 0.28 \\
(8 \%)>0.05^{\mathrm{a}}\end{array}$ & $\begin{array}{c}0.8 \pm 0.12 \\
(-33 \%) \leq 0.001^{\mathrm{a}}\end{array}$ & $\begin{array}{c}1.1 \pm 0.20 \\
(-8 \%)>0.05^{\mathrm{a}} \leq 0.01^{\mathrm{b}}\end{array}$ \\
\hline & Brain & $0.60 \pm 0.08$ & $\begin{array}{c}0.65 \pm 0.06 \\
(8 \%)>0.05^{\text {a }}\end{array}$ & $\begin{array}{c}0.43 \pm 0.02 \\
(-28 \%) \leq 0.001^{a}\end{array}$ & $\begin{array}{c}0.56 \pm 0.04 \\
(-7 \%)>0.05^{\mathrm{a}} \leq 0.001^{\mathrm{b}}\end{array}$ \\
\hline
\end{tabular}

- Data are expressed as means \pm standard deviation $(n=6)$.

- The number between brackets shows the percentage of change from the respective control value.

- a: Significance vs control, ${ }^{\text {b: }}$ Significance vs EM.

- Differences between means were considered significant at $\mathrm{P} \leq 0.05$, highly significant at $p \leq 0.01$ and very highly significant at $\mathrm{P} \leq 0.001$, non-significant at $\mathrm{P}>0.05$.

TABLE 4. The level of total manganese (Mn), iron (Fe), copper ( $\mathrm{Cu})$, and zinc $(\mathrm{Zn})$ in the liver and brain of rats in the different groups.

\begin{tabular}{|c|c|c|c|c|c|}
\hline & Organ & Control & Garlic & EMF & Garlic+EMF \\
\hline \multirow{2}{*}{$\begin{array}{l}\text { Mn } \\
(\mu \mathrm{g} / \mathrm{g} \text { fresh tissue })\end{array}$} & Liver & $8.0 \pm 0.9$ & $\begin{array}{c}8.8 \pm 1.2 \\
(10 \%)>0.05^{a}\end{array}$ & $\begin{array}{c}5.5 \pm 1.1 \\
(-31 \%) \leq 0.001^{a}\end{array}$ & $\begin{array}{c}7.3 \pm 1.0 \\
(-9 \%)>0.05^{\mathrm{a}} \leq 0.01^{\mathrm{b}}\end{array}$ \\
\hline & Brain & $3.0 \pm 0.5$ & $\begin{array}{c}3.4 \pm 0.4 \\
(13 \%)>0.05^{\mathrm{a}}\end{array}$ & $\begin{aligned} 2.1 & \pm 0.3 \\
(-30 \%) & \leq 0.001^{\mathrm{a}}\end{aligned}$ & $\begin{array}{c}2.6 \pm 0.3 \\
(-13 \%)>0.05^{\mathrm{a}} \leq 0.01^{\mathrm{b}}\end{array}$ \\
\hline \multirow{2}{*}{$\begin{array}{l}\mathrm{Fe} \\
(\mu \mathrm{g} / \mathrm{g} \text { fresh tissue })\end{array}$} & Liver & $73 \pm 3$ & $\begin{array}{c}72 \pm 5 \\
(-1 \%)>0.05^{a}\end{array}$ & $\begin{array}{c}96 \pm 6 \\
(31 \%) \leq 0.001^{\mathrm{a}}\end{array}$ & $\begin{array}{c}80 \pm 5 \\
(10 \%) \leq 0.01^{\mathrm{a}} \leq 0.001^{\mathrm{b}}\end{array}$ \\
\hline & Brain & $36 \pm 3$ & $\begin{array}{c}39 \pm 5 \\
(8 \%)>0.05^{a}\end{array}$ & $\begin{array}{c}46 \pm 4 \\
(28 \%) \leq 0.001^{\mathrm{a}}\end{array}$ & $\begin{array}{c}41 \pm 4 \\
(14 \%) \leq 0.01^{\mathrm{a}} \leq 0.01^{\mathrm{b}}\end{array}$ \\
\hline \multirow{2}{*}{$\begin{array}{l}\mathrm{Cu} \\
(\mu \mathrm{g} / \mathrm{g} \text { fresh tissue })\end{array}$} & Liver & $2.7 \pm 0.1$ & $\begin{array}{c}2.6 \pm 0.4 \\
(-4 \%)>0.05^{a}\end{array}$ & $\begin{array}{c}3.5 \pm 0.7 \\
(30 \%) \leq 0.01^{\mathrm{a}}\end{array}$ & $\begin{array}{c}2.8 \pm 0.3 \\
(4 \%)>0.05^{\mathrm{a}} \leq 0.01^{\mathrm{b}}\end{array}$ \\
\hline & Brain & $1.7 \pm 0.1$ & $\begin{array}{c}1.6 \pm 0.2 \\
(-6 \%)>0.05^{a}\end{array}$ & $\begin{array}{c}2.1 \pm 0.2 \\
(23 \%) \leq 0.001^{\mathrm{a}}\end{array}$ & $\begin{array}{c}1.8 \pm 0.2 \\
(6 \%)>0.05^{\mathrm{a}} \leq 0.01^{\mathrm{b}}\end{array}$ \\
\hline \multirow{2}{*}{$\begin{array}{l}\mathrm{Zn} \\
(\mu \mathrm{g} / \mathrm{g} \text { fresh tissue })\end{array}$} & Liver & $38 \pm 3.3$ & $\begin{array}{c}39 \pm 4.9 \\
(3 \%)>0.05^{a}\end{array}$ & $\begin{array}{c}29 \pm 3 \\
(-24 \%) \leq 0.001^{a}\end{array}$ & $\begin{array}{c}32 \pm 2 \\
(-16 \%) \leq 0.01^{\mathrm{a}} \leq 0.01^{\mathrm{b}}\end{array}$ \\
\hline & Brain & $11 \pm 1.2$ & $\begin{array}{c}12 \pm 1.5 \\
(9 \%)>0.05^{\mathrm{a}}\end{array}$ & $\begin{array}{c}8 \pm 0.9 \\
(-27 \%) \leq 0.001^{\mathrm{a}}\end{array}$ & $\begin{array}{c}9 \pm 1.0 \\
(-18 \%) \leq 0.01^{\mathrm{a}}>0.05^{\mathrm{b}}\end{array}$ \\
\hline
\end{tabular}

- Data are expressed as means \pm standard deviation $(n=6)$.

- The number between brackets shows the percentage of change from the respective control value.

- a: Significance vs control, b: Significance vs EM.

- Differences between means were considered significant at $\mathrm{P} \leq 0.05$, highly significant at $p \leq 0.01$ and very highly significant at $\mathrm{P} \leq 0.001$, non-significant at $\mathrm{P}>0.05$. 
The exposure of male albino rats to $950 \mathrm{MHz}$ has triggered oxidative stress, in brain and liver tissues as demonstrated by a significant elevation in the level of malondialdehyde (MDA), an end product of lipid peroxidation and nitric oxide (NO) (Table 1). Also, a significant increase was recorded in xanthine oxidase (XO) activity, while a significant decrease was recorded in the activity of xanthine dehydrogenase (XDH), compared to their respective values in control rats (Table 2). The activity of the antioxidant enzymes superoxide dismutase (SOD), catalase (CAT) and glutathione peroxidase (GSH-Px) was significantly decreased (Table 3). The levels of total iron, total copper were significantly increased, while the levels of total zinc, and total manganese were significantly decreased, compared to their respective control levels (Table 4). Garlic treatment, has significantly attenuated the impact of $950 \mathrm{MHz}$ in the brain and liver.

\section{Discussion}

With the rapid development of electronic technologies, the health hazards induced by nonionizing radiation have been growing in recent years. Technological devices such as mobile phones, computers, wireless networks, household appliances and other electronic equipment have become essential components of daily life, however, despite making life easier, they may also cause a number of health problems due to the increased durations of exposure to radiofrequency and microwaves (Yu \& Peng, 2017; Samta et al., 2017 and Kivrak et al., 2017).

In the current study, exposure of rats to $950 \mathrm{MHz}$ for $1 \mathrm{hr} 3$ times a week for 7 weeks has promoted oxidative stress in the brain and liver verified by a significant increase of MDA, NO, and $\mathrm{XO}$ accompanied by a significant decrease in $\mathrm{XDH}$, SOD, CAT and GSH-Px compared to the control group. Increased lipid peroxidation was accompanied by an increase in the levels of $\mathrm{Fe}$ and $\mathrm{Cu}$ and a decrease of $\mathrm{Mn}$ and $\mathrm{Zn}$ that may be attributed to alteration in the permeability of plasma membranes.

These changes may indicate the high vulnerability of brain (Cao et al., 2004; MartinezSamano et al., 2012 and Ghanbari et al., 2016) and liver (Liu et al., 2013 and Kivrak et al., 2017) and their susceptibility to oxidative stress (Ragy, 2015). The results corroborate the findings of
Samta et al. (2017) that the exposure of rats to $900 \mathrm{MHz}$ EMR for $2 \mathrm{hr}$ daily for 3 months causes a considerable damage in the liver, and brain.

The results are in line with previous findings that exposure to radiofrequency raises nitricoxide (NO), induces lipid peroxidation (Ozgur et al., 2010), decrease catalase (Sokolovic et al., 2008 and Odaci et al., 2015), superoxide dismutase (SOD), and glutathione peroxidase (GSH-Px) activities (Ozgur et al., 2010 and Sepehrimanesh et al., 2017), increase the activity of xanthine oxidase (Sokolovic et al., 2008). The decreased activity of enzyme might be attributed to changes in transcription and protein expression (Friedman et al., 2007).

Meanwhile, the increase of MDA and NO may be attributed to imbalance in iron homeostasis that increases free iron levels and leads to the formation of hydroxyl radicals via the Fenton reaction, followed by lipid peroxidation and calcium leakage from internal storage that trigger nitricoxide synthesis, which is responsible for damage to DNA and other macromolecules(Lai \& Singh, 2004).

The elevated MDA concentration corroborates the cytotoxic effect of non-ionizing radiation, where an elevated oxy radical generation and subsequent cell membrane disruptions were reported to be the reasons for electromagnetic field induced cell damage (Dindic et al., 2010).

In the current study, the significant decrease of SOD, CAT, and GPx activities in the brain and liver point out that alterations in the level of antioxidants, and enzymological activity could be considered the indicators of deteriorating animal homeostasis that further resulted in stress and declined the functional ability (Gecit et al., 2014 and Saravanan et al., 2012). Oxidative insult via deterioration of antioxidant defense capacity is apathogenic pathway involved in all the organ dysfunction or disorders (Saravanan et al., 2012). Compelling evidence has demonstrated that EMF exposure is capable of causing substantial oxidative damage to the body (Sharma et al. 2014; Aydin \& Akar et al., 2011 and Maaroufi et al., 2014).

The levels of trace elements can vary considerably depending on age, sex, diet, geographical and climatic conditions, or genetic 
factors. The concentration of an element may also change by physical or chemical factors (Shen et al., 2005).

In the current study, the changes in the level of total iron, copper, zinc and manganese in liver and brain tissues might indicate the detrimental effects of EMF exposure. It is well documented that many elements are co-factors of several antioxidant enzyme systems. In this context, zinc and copper in SOD (Zelko et al., 2002) play a role in quenching free radicals through reduction of the peroxidation ratio and breaking the free-radical production chain.

Garlic has long been used for medicinal purposes by people from many cultures for centuries (Lawson, 1998). The main pharmacological effects of garlic are attributed to 'allicin', an organosulphur compound that exhibits antioxidant (Yousef et al., 2015), hypocholesterolemic, and hypoglycemic action (Duvvu et al., 2018). In the current study, the administration of Garlic $(500 \mathrm{mg} / \mathrm{kg}$ body weight), to normal rats, has not induced toxic effects in liver and brain tissues as demonstrated by the normal level of oxidants, and antioxidants as well as iron, copper, zinc, and manganese, compared to their corresponding levels in the control group.

Nevertheless, the administration of garlic extract to the rats, half an hour before exposure to $950 \mathrm{MHz}$, has significantly attenuated oxidative stress, and induced a remarkable improvement in the level of trace elements, when compared to their values in the brain and liver of irradiated rats. This could be attributed to the presence of organosulfur compounds (Tapiero et al., 2004). In addition, Alliums sativum or garlic contains various substances including minerals, carbohydrates, proteins, fats and vitamins. Vitamins found in garlic include vitamin $\mathrm{A}$, various kinds of vitamin $\mathrm{B}$, such as riboflavin, thiamine, nicotinic acid, and vitamins $\mathrm{C}$ and $\mathrm{E}$. Moreover, garlic is a rich source of many elements including zinc, calcium, potassium, manganese, magnesium (Saada, 2013). Also, garlic contains germanium and selenium that play an important role in normalizing the oxygen utilization in the cells (Hussein et al., 2007).

In the current study, garlic administration has effectively alleviated oxidative stress as evidenced by the enhancement of SOD, catalase and GSH-Px activities in liver and brain tissues.
This elevation of the antioxidant capacity suggests that garlic extract protects from oxidative stress (Ghalehkandi, 2014); promotes the scavenging of reactive free radicals that improve the antioxidant enzyme activities and supported by the decreased levels of NO and MDA (Ghalehkandi et al., 2013).

The protective property of garlic may be attributed to the presence of organosulfur compounds, which have antioxidant and detoxifying properties. This detoxifying effect is explained by the induction of antioxidant enzymes (Munday \& Munday, 2004).

According to the results obtained in the current study, there is a possibility that orally administered garlic extract exerts a preventive effect on injury progression in EMF treated rats through its indirect antioxidant action to maintain antioxidant defense system in addition to its direct antioxidant action to scavenge ROS and to inhibit lipid peroxidation.

\section{Conclusion}

In Conclusion, EMFs interaction with biological systems may cause deleterious changes in tissues. Garlic extract may attenuate these changes.

\section{References}

Aebi, H. (1984) Catalase in vitro. Methods in Enzymology, 105, 121-126.

Ahmed, N.A., Radwan, N.M., Aboul Ezz, H.S. and Salama, N.A. (2017) The antioxidant effect of Green Tea Mega EGCG against electromagnetic radiationinduced oxidative stress in the hippocampus and striatum of rats. Electromagnetic Biology and Medicine, 36(1), 63-73.

Alnaqeeb, M.A., Al-Qattan, K.K. and Ali, M. (1999) The antihypertensive effect of garlic (Allium sativum L.) in the rat two- kidney-one-clip Goldblatt model. J. Ethnopharmacol. 66(2), 217-222.

Aydin, B. and Akar, A. (2011) Effects of a 900-MHz electromagnetic field on oxidative stress parameters in rat lymphoid organs, polymorphonuclear leukocytes and plasma. Archives of Medical Research, 42(4), 261-7.

Blumenthal, M. (2005) Herb sales down 7.4 percent in mainstream market. Herbal Gram. Am. Bot.Coun. 63, 21- 27 . 
Calcabrini, C., Mancini, U., De Bellis, R., Diaz, A.R., Martinelli, M., Cucchiarini, L., Sestili, P., Stocchi, V. and Potenza, L. (2017) Effect of extremely lowfrequency electromagnetic fields on antioxidant activity in the human keratinocyte cell line NCTC 2544. Biotechnol. Appl. Biochem. 64(3), 415-422.

Cao, G.F., Tong, J., Wang, J., Liu, Q. and Jin, Y.L.(2004) Study on effect of weak radio-frequency electomagnetic field on neurobehavioral of human and mice. Ind. Hlth. Occup. Dis. 30, 135-7.

Challis, L.J. (2005) Mechanisms for interaction between RF fields and biological tissue. Bioelectromagnetics Suppl. 7, S98-S106.

Demers, P., Findlay, R., Foster, K.R., Kolb, B., Moulder, J., Nicol, A., Prato, F. and Stam R. (2014) Expert Panel Report on A Review of Safety Code 6 (2013): Health Canada's Safety Limits for Exposure to Radiofrequency Fields. Royal Society of Canada, Ottawa, ON. ISBN: 978-1-928140-009, p. 15 .

Deniz, O.G., Kıvrak, E.G., Kaplan, A.A. and Altunkaynak, B.Z. (2017) Effects of folic acid on rat kidney exposed to $900 \mathrm{MHz}$ electromagnetic radiation. Journal of Microscopy and Ultrastructure, 5(4), 198-200.

Dindic, B., Sokolović, D., Krstić, D., Petković, D., Jovanović, J. and Muratović, M. (2010) Biochemical and histopathological effects of mobile phone exposure on rat hepatocytes and brain. Acta Medica Medianae, 49(1), 37-42.

Durney, C.H., Massoudi, H. and Iskander, M.F. (1986) "Radiofrequency Radiation Dosimetry Handbook", $4^{\text {th }}$ ed, United states Air Force research laboratory technical report USAF SAMM-TR-85-73. Books Air Force Base Texas USA.

Duvvu, M.V., Rao, K.A., Seshaiah, C.V. and Kumar, D.S. (2018) Effect of garlic supplementation on the blood biochemical profile of Murrah Buffalo Calves. Int. J. Curr. Microbiol. App. Sci. 3, 2973-2983.

Flohé, L. (1988) Glutathione peroxidase. Basic Life Sci. 49, 663-668.

Friedman, J., Kraus, S., Hauptman, Y., Schiff, Y. and Seger, R. (2007) Mechanism of short-term ERK activation by electromagnetic fields at mobile phone frequencies. Biochem. J. 405(3), 559-568.
Gecit, I., Karak, S. and Yuksel, M.B. (2014) Effect of short term treatment with levosimendan on antioxidant stress in renal tissues of rats. Toxicology and Industrial Health, 30, 47-31.

Ghalehkandi, J.G. (2014) Garlic (Allium sativum) juice protects from semen oxidative stress in male rats exposed to chromium chloride. Anim. Reprod. 11(4), 526-532.

Ghalehkandi, J.G., Ebrahimnezhad, Y. and Sis, N.M. (2013) The effect of aqueous garlic extract and chromium chloride complement on tissue antioxidant system of male rats. The Journal of Animal and Plant Science, 23(1), 56-59.

Ghanbari, A.A., Shabani, K. and Mohammad nejad, D. (2016) protective effects of vitamin e consumption against 3MT electromagnetic field effects on oxidative parameters in substantia nigra in rats. Basic Clin. Neurosci. 7(4), 315-322.

Hao, Y.H., Zhao, L. and Peng, R.Y. (2015) Effects of microwave radiation on brain energy metabolism and related mechanisms. Mil. Med. Res. 2, 4.

Harrison, R. (2002) Structure and function of xanthine oxidoreductase: Where are we now? Free Radic. Biol. Med. 33(6), 774-797.

Hussein, J.S., Oraby, F.S. and El-Shafey, N. (2007) Antihepatotoxic effect of garlic and onion oils on ethanol-induced liver injury in rats. Journal of Applied Sciences Research, 3(11), 1527-1533.

Kaminski, W. and Jewezska, M.M. (1979) Intermediate dehydrogenase oxidase form of xanthine oxidoreductase in rat liver. Biochem. J. 181(1), 177-182.

Kirbright, G. and Sargent, M. (1974) "Atomic Absorption and Fluorescence Spectroscopy". Academic Press. London.,

Kirkman, H.N., Rolfo, M., Ferraris, A.M. and Gaetani, G.F. (1999) Mechanisms of protection of catalase by NADPH. Kinetics and stoichiometry. J. Biol. Chem. 274(20), 13908-13914.

Kivrak, E.G., Yurt, K.K., Kaplan, A.A., Alkan, I. and Altun, G. (2017) Effects of electromagnetic fields exposure on the antioxidant defense system. Journal of Microscopy and Ultrastructure, 5(4), 167-176. 
Lai, H. and Singh, N.P. (2004) Magnetic-field-induced DNA strand breaks in brain cells of the rat. Environ. Health Perspect, 112(6), 687-694.

Lawson, L.D. (1998) Garlic: A review of its medicinal effects and indicated active compounds. Am. Chem. Soci. 177-209.

Liu, X., Zhao, L.Y., Chen, H.L., Liu, C., Liu, X.D. and Ma, S.M. (2013) Effect of exposure to extremely low-frequency electromagnetic fields on liver function of workers. Zhonghua Lao. Dong. Wei. Sheng. Zhi.Ye. Bing.Za.Zhi. 31(8), 599-601.

Maaroufi, K., Had-Aissouni, L., Melon, C., Sakly, M., Abdelmelek, H., Poucet, B. and Save, E. (2014) Spatial learning, monoamines and oxidative stress in rats exposed to $900 \mathrm{MHz}$ electromagnetic field in combination with iron overload. Behav. Brain Res. 258, 80-89.

Martinez-Samano, J., Torres-Duran, P.V., JuarezOropeza, M.A. and Verdugo-Diaz, L. (2012) Effect of acute extremely low frequency electromagnetic field exposure on the antioxidant status and lipid levels in rat brain. Arch. Med. Res. 43(3), 183-189.

Megha, K., Deshmukh, P.S., Banerjee, B.D., Tripathi, A.K. and Abegaonkar, M.P. (2012) Microwave radiation induced oxidative stress, cognitive impairment and inflammation in brain of Fischer rats. Indian J. Exp. Biol. 50(12), 889-896.

Meneshian, A. and Bulkley, G. B. (2002) The physiology of endothelial xanthine oxidase: from urate catabolism to reperfusion injury to inflammatory signal transduction. Microcirculation, 9(3),161-75.

Miranda, K.M., Espey, M.G. and Wink, D.A. (2001) A rapid simple spectrophotometric method for simultaneous detection of nitrate and nitrite. Nitric Oxide, 5(1), 62-71.

Munday, R. and Munda, C.M. (2004) Induction of phase II enzymes by aliphatic sulfides derived from garlic and onions: An overview. Methods Enzymol. 382, 449-456.

Niskikimi, M., Rao, N. and Yaki, K. (1972) The occurrence of superoxide anion in the reaction of reduced phenazinemethosulfate and molecular oxygen. Biochem. Biophys. Res. Commun. 46(2), 849-854.
Odaci, E., Unal, D., Mercantepe, T., Topal, Z., Hanci, H. and Turedi, S. et al. (2015) Pathological effects of prenatal exposure to a $900 \mathrm{MHz}$ electromagnetic field on the 21-day-old male rat kidney. Biotech. Histochem. 90, 93-101.

Ozgur, E., Guler, G. and Seyhan, N. (2010) Mobile phone radiation-induced free radical damage in the liver is inhibited by the antioxidants $\mathrm{N}$-acetyl cysteine and epigallocatechin-gallate. Int. J. Radiat. Biol. 86(11), 935-945.

Paglia, D. and Valentine, W. (1967) Studies on the quantitative and qualitative characterization of erythrocyte glutathione peroxidase. Lab. Clin. Med. 70(1), 158.169.

Ragy, M.M. (2015) Effect of exposure and withdrawl of $900 \mathrm{MHz}$ electromagnetic waves on brain, kidney and liver oxidative stress and some biochemical parameters in male rats. Electromagnetic Biology and Medicine, 34(4), 279-84.

Saada, M.E. (2013) Comparative study on concentration of some minerals found in garlic (Allium sativum Linn.) species grown in some african countries. Journal of Biology and Life Science, 4(1).

Samta, S., Anjali, S. and Sangeeta, S. (2017) Effect of electromagnetic radiation on vital organs in rats. Octa Journal of Biosciences, 5(1), 1-4.

Saravanan, M., Devi, U.K. and Malarvizhi, A. (2012) Effects of ibuprofen on hematological, biochemical and enzymological parameters of blood in an Indian major carp Cirrhinusmrigala. Enviromental Toxicology and Pharmacology, 34(1), 14-22.

Sepehrimanesh, M., Kazemipour, N., Saeb, M., Nazifi, S. and Davis, D.L. (2017) Proteomicanalysis of continuous $900-\mathrm{MHz}$ radiofrequency electromagnetic field exposure in testicular tissue: A rat model of human cell phone exposure. Environ. Sci. Pollut. Res. Int. 24(15), 13666-13673.

Sharma, S., Raghuvanshi, B.P.S. and Shukla, S. (2014) Toxic effects of lead exposure in rats: Involvement of oxidative stress, genotoxic effect, and the beneficial role of $\mathrm{N}$-acetylcysteine supplemen with selenium. J. Environ. Pathol. Toxicol. Onco. 33(1), 19-32.

Shedid, S.M., Saada, H.N., Eltahawy, N.A. and Hammad, A.S. (2018) Curative role of pantothenic 
acid in brain damage of gamma irradiated rats. Ind. J. Clin. Biochem. 33(3), 314-321.

Shen, S.G., Li, H., Zhao, Y.Y., Zhang, Q.Y. and Sun, H.W. (2005) The distribution patterns of trace elements in the blood and organs in a rabbit experimental model of copper pollution and study of haematology and biochemistry parameters. Environmental Toxicology and Pharmacology, 19(2), 379-384.

Sokolovic, D., Djindjic, B., Nikolic, J., Bjelakovic, G., Pavlovic, D. and Kocic, G.et al. (2008) Melatonin reduces oxidative stress induced by chronic exposure of microwave radiation from mobile phones in rat brain. J. Radiat. Res. 49(6), 579-586.

Tapiero, H., Townsend, D.M. and Tew, K.D. (2004) Organosulfur compounds from alliaceae in the prevention of human pathologies. Biomed. Pharmacother. 58(3), 183-193.

Tkalec, M., Malaric, K. and Pevalek-Kozlina, B. (2007) Exposure to radiofrequency radiation induces oxidative stress in duckweed Lemna minor L. Sci. Total. Environ. 388(1-3), 78-89.
Yoshioka, T., Kawada, K., Shimada, T. and Mori, M. (1979) Lipid peroxidation in maternal and cord blood and protective mechanism against activatedoxygen toxicity in the blood. Am. J. Obstet. Gynecol. 135(3), 372-376.

Yousef, A.E., Abdel El Hakeim, T. and Thakeb, M.M. (2015) The antioxidant effect of garlic powder on rats treated by different doses of chromium chloride. Egypt. J. Chem. Environ. Health, 1, 379388.

Yu, C. and Peng, R. (2017) Biological effects and mechanisms of shortwave radiation, a review. Mil. Med. Res. 4, 24.

Zelko, I.N., Mariani, T.J. and Folz, R.J. (2002) Superoxide dismutase multigene family: Acomparison of the CuZn-SOD (SOD1), Mn-SOD (SOD2), and EC-SOD (SOD3) gene structures, evolution, and expression. Free Radic. Biol. Med. 33(3), 337-49.

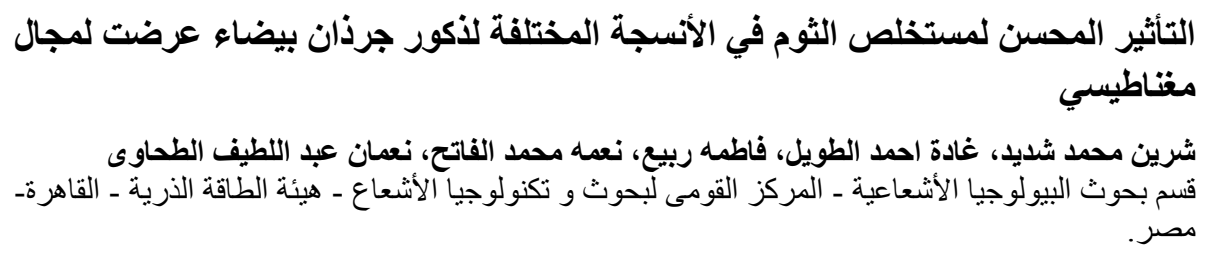

أصبح استخدام الهو اتف المحولة وأجهزة الكمبيوتر المحمولة والثبكات اللاسلكية مكونات أساسية للحياة اليومية.

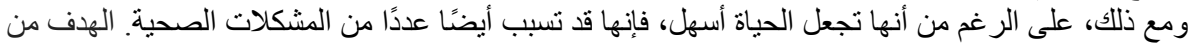

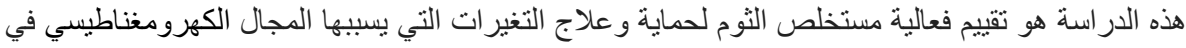

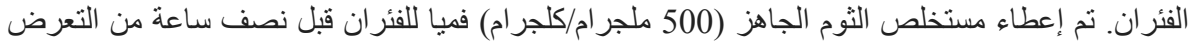

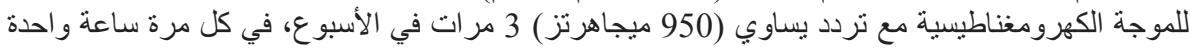

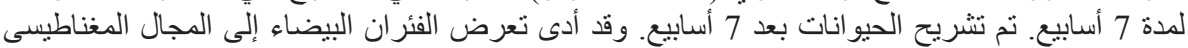

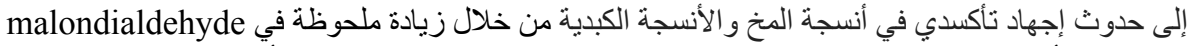

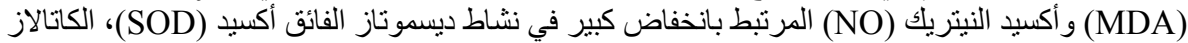
و الجلوناثيون بيروكسيديز (CAT)

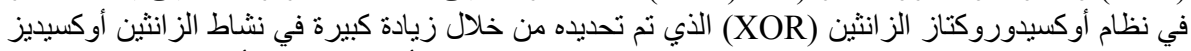
(XO)

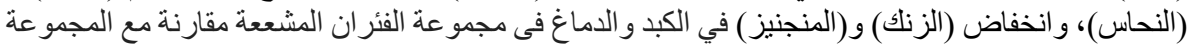

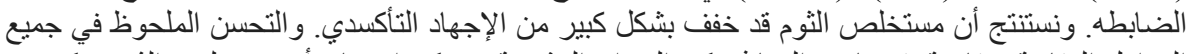

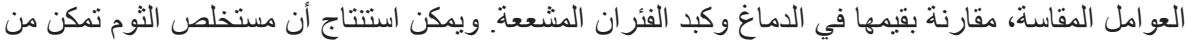

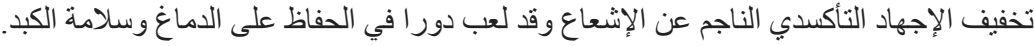

